OPEN ACCESS

Edited by:

Robert James Hayashi,

Washington University School of Medicine in St. Louis, United States

Reviewed by:

Daniel Wolff,

University Hospital Regensburg,

Germany

Eva Maria Weissinger,

Hannover Medical School, Germany

Anita Lawitschka,

St. Anna Children's Cancer Research

Institute (CCRI), Austria

*Correspondence:

Jacob Rozmus

jrozmus@cw.bc.ca

Specialty section:

This article was submitted to Alloimmunity and Transplantation,

a section of the journal

Frontiers in Immunology

Received: 20 June 2020

Accepted: 07 December 2020

Published: 04 February 2021

Citation:

Rozmus J (2021) Monogenic Immune

Diseases Provide Insights Into the

Mechanisms and Treatment of

Chronic Graft-Versus-Host Disease.

Front. Immunol. 11:574569.

doi: 10.3389/fimmu.2020.574569

\section{Monogenic Immune Diseases Provide Insights Into the Mechanisms and Treatment of Chronic Graft-Versus-Host Disease}

\author{
Jacob Rozmus ${ }^{1,2 *}$ \\ 1 Division of Pediatric Hematology, Oncology \& BMT, Department of Pediatrics, BC Children's Hospital, University of British \\ Columbia, Vancouver, BC, Canada, ${ }^{2}$ Michael Cuccione Childhood Cancer Research Program, BC Children's Hospital \\ Research Institute, Vancouver, BC, Canada
}

Chronic graft-versus-host disease (GvHD) has become a leading cause of morbidity and mortality following allogeneic hematopoietic stem cell transplantation (HSCT) and can burden patients with devastating and lifelong health effects. Our understanding of the pathogenic mechanisms underlying chronic GvHD remains incomplete and this lack of understanding is reflected by lack of clear therapeutic approaches to steroid refractory disease. Observations predominantly from mouse models and human correlative studies currently support a three phase model for the initiation and development of chronic GvHD: 1) early inflammation and tissue damage triggers the innate immune system. This leads to inflammatory cytokine/chemokine patterns that recruit effector immune cell populations; 2) chronic inflammation causes the loss of central and peripheral tolerance mechanisms leading to emergence of pathogenic $B$ and $T$ cell populations that promote autoimmune and alloimmune reactions; 3) the dysregulated immunity causes altered macrophage polarization, aberrant tissue repair leading to scarring and end organ fibrosis. This model has led to the evaluation of many new therapies aimed at limiting inflammation, targeting dysregulated signaling pathways and restoring tolerance mechanisms. However, chronic GvHD is a multisystem disease with complex clinical phenotypes and it remains unclear as to which cluster of patients will respond best to specific therapeutic strategies. However, it is possible to gain novel insights from immune-related monogenic diseases. These diseases either share common clinical manifestations, replicate steps from the three phase chronic GvHD model or serve as surrogates for perfectly targeted drugs being investigated in chronic GVHD therapy. In this review, we will summarize the evidence from these monogenic immune related diseases that provide insight into pathogenic pathways in chronic GvHD, rationales for current therapies and novel directions for future drug discovery.

Keywords: primary immunodeficiency diseases, chronic graft-versus-host disease, hematopoietic stem cell transplantation, inflammation, $\mathrm{T}$ cell, $\mathrm{B}$ cell 


\section{CHRONIC GRAFT-VERSUS-HOST DISEASE}

Chronic graft-versus-host disease (cGvHD) is now the leading cause of morbidity and mortality post-hematopoietic stem cell transplantation $(1,2)$. cGvHD is a pleomorphic syndrome that resembles autoimmune and other immunologic disorders that occurs between 3 and 15 months after HCT. Chronic GvHD can affect almost any organ including skin, liver, eyes, mouth, lungs, gastrointestinal tract, neuromuscular system, or genitourinary tract. The spectrum of disease manifestations and diagnostic criteria were updated in 2014 after the second National Institutes of Health (NIH) Consensus Conference on cGvHD (3). The rates of $\mathrm{cGvHD}$ depend on several variables and can range from as low as $6 \%$ in matched sibling cord blood transplants to as high as $65 \%$ in matched unrelated donor (MUD) peripheral blood stem cell (PBSC) transplants (4).

Our understanding of the pathophysiology of cGvHD has improved over the last decade to the point where there is now a well-accepted three phase model of cGvHD development supported by mouse models, correlative clinical studies and clinical trials (5). The three phases are: 1) acute inflammation and tissue injury trigger inflammatory cytokine/chemokine patterns, mediated through the innate immune system, that recruit effector immune cell populations; 2) chronic inflammation causes a loss of tolerance that disrupts the homeostasis of the adaptive immune system leading to the emergence of pathogenic $\mathrm{B}$ and $\mathrm{T}$ cell populations; 3) the dysregulated immune response causes altered macrophage polarization causing an aberrant tissue repair mechanism leading to excessive end organ fibrosis and scarring.

Despite these insights, clinicians continue to struggle to identify the optimal therapy for patients with cGvHD who do not respond to front-line corticosteroids or patients who cannot be successfully weaned off corticosteroids.

\section{WHY STUDY RARE DISEASES?}

Rare inherited monogenic diseases affecting innate and adaptive immunity provide a unique opportunity to understand the role of specific genes, molecules, pathways and cell types in our immune system (6). Unfortunately, in the past these rare diseases were often considered medical outliers and neglected compared to more polygenic, multifactorial common disorders. However, they all operate under the same biological principles and these rare diseases are actually much simpler pathologically then common diseases. These human models demonstrate the function of a particular gene in an otherwise controlled experiment of nature, in which everything else is identical except for the one single factor which is the root cause of the resulting disease phenotype. Better understanding rare diseases not only directly benefits those patients afflicted but the recognition of a molecular defect can lead to potential therapies. Mutations that alter the level of activity of gene products can be thought of as surrogates for perfectly targeted drugs (7).
Their study provides the means to better understand complex acquired diseases in a number of ways:

1. An acquired disease may have a specific phenotype that is specifically missing in an inherited disease due to the absence of a key molecule. By pharmacologically inhibiting this factor you may eliminate the phenotype, therefore the inherited disease informs a potential new target.

2. An acquired disease may have a specific phenotype that mimics that seen in an monogenic disease associated with altered function (gain or loss of function) of a key molecule or cell type; inherited disease again provides potential new target or supports the addition of a key factor into treatment, such as adding an agonist or cell type. The emergence of cellular therapies has given clinicians the ability to treat disease with a wide variety of manipulated cell types in addition to the wellestablished therapy of hematopoietic stem cell transplant.

3. A new targeted therapy may be trialed based on mouse models or human correlative clinical studies of a specific disease and there is a corresponding monogenic disease involving that factor; the rare disease may provide insights into unintended consequences of targeting that factor in other biological pathways.

With these principles in mind, the purpose of this review is to use our evolving understanding of monogenic immune disorders to provide a rationale for previous and ongoing therapies in cGvHD and potentially provide new avenues for intervention based on the pathophysiology of cGvHD (Table 1).

\section{SIMILARITIES BETWEEN CHRONIC GVHD AND PRIMARY IMMUNE DISORDERS}

Chronic GvHD is fundamentally a disorder of immune regulation. A successful HCT requires: 1) reconstitution of normal innate and adaptive cellular immune responses to infectious pathogens and the 2) induction of immune tolerance to non-self antigens and in the case of malignant disease, while preserving the graft-versus-tumor effect.

The persistent alloreactivity in cGvHD is driven step-wise by increased expression of host-derived molecules that result from tissue damage. This leads to the expansion of pathogenic $\mathrm{T}$ and $\mathrm{B}$ cell populations that escape tolerance and are allowed to persist due to the failure of suppressive regulatory mechanisms. This promotes chronic inflammation that triggers aberrant repair mechanisms. Therefore, this review will focus on primary immunodeficiencies associated with defects in intrinsic or innate immunity, autoimmunity and dysregulation of lymphocyte homeostasis.

\section{DEFECTS INVOLVING THE INNATE IMMUNE SYSTEM}

The intestinal epithelium, an integral component of innate immunity, is altered in a number of ways during the HCT 
TABLE 1 | Potential therapies targeting the pathophysiology of each phase of chronic graft-versus-host disease.

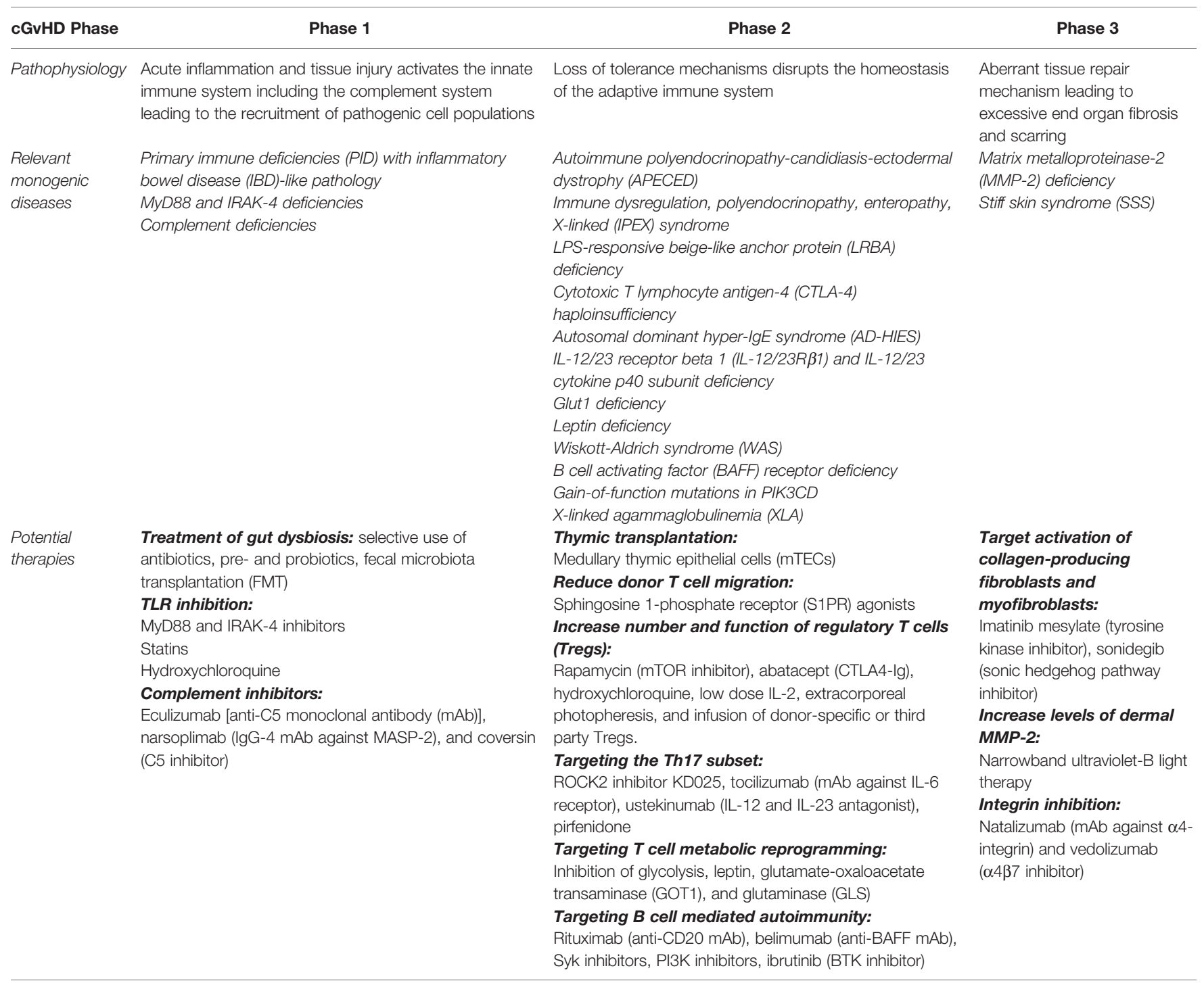

The bolded text in italics describes the mechanism/class of medications that addresses the pathophysiology of that phase of cGVHD.

process; complications of the primary disease, gastrointestinal infections, conditioning chemotherapy and radiation cause direct intestinal damage and the use of broad-spectrum antibiotics and varied diets disrupt gut microbiota. Affected cell types include: 1) intestinal stem cells, impairing epithelial regeneration, 2) intestinal epithelial cells, which comprises barrier function, 3) Paneth cells, leading to decreased secretion of antimicrobial peptides, and 4) goblet cells, which depletes the mucus barrier. The cumulative effect is a dysbiosis associated with decreased commensal bacterial function and diversity, increased gut permeability and bacterial translocation leading to increased local inflammation that disrupts immune homeostasis (8).

Many primary immune deficiencies are associated with microbial dysbiosis, which manifests clinically as inflammatory bowel disease (IBD)-like pathology (9) and may alter the clinical phenotype of a common genetic susceptibility. Underlying pathogenic mechanisms include the absence of secretory IgA which normally promotes the clearance of antigens and pathogenic bacteria from the gut microbiota (10) and increased translocation of lipopolysaccharide (LPS) (11). Therapies such as the selective use of antibiotics, prebiotics, probiotics and fecal microbiota transplantation, aimed at restoring the gut microbiota may prove beneficial in $\mathrm{cGvHD}$ and are actively being investigated (12).

Early inflammation in patients post-HCT is triggered by the activation of innate pattern-recognition receptors (PRRs) such as Toll-like receptors (TLRs) and nucleotide oligomerization domain (NOD)-like receptors (NLRs) on host antigen presenting cells (APCs) by viral and bacterial components and endogenous dangerous molecules termed danger-associated molecular patterns (DAMPs). These signals are released due to endothelial and epithelial cell damage in the GI tract caused by underlying disease, infection and transplant conditioning. TLR signaling in APCs such as dendritic cells enhance antigen 
endocytosis and autophagy and augments the assembly of key antigen transport and processing systems (13). In turn, activated host and donor APCs stimulate donor T cells either directly through donor $\mathrm{T}$-cell receptors that recognize minor histocompatibility antigens, foreign MHC molecules and allogeneic peptides or indirectly through the release of proinflammatory cytokines and chemokines such as IL-1 $\beta$, IL-6, IL-8, IL-10, IL-12, IL-21, IL-23, TGF $\beta$ and TNF $\alpha$. Compared with non-GVHD patients after HSCT and healthy donor controls, TLR4-mediated NF- $\mathrm{KB}$ signaling-related genes including TLR4, NF- $\kappa \mathrm{B}$, IL- 6 and intercellular adhesion molecules 1 (ICAM-1) were significantly increased in patients with cutaneous cGVHD (14).

In innate immune cells such as dendritic cells, MyD88 is the critical adaptor molecule that bridges TLRs to the IRAK family of kinases, which in turn stimulate a signaling cascade that results in NF- $\kappa \beta$ activation $(15,16)$. Germline MyD88 and IRAK-4 deficiencies predispose patients to recurrent life-threatening bacterial diseases, such as invasive pneumococcal disease in particular, with weak signs of inflammation (17).

There is evidence that TLR signaling contributes to the early activation of APCs and priming of donor T cells. TLR inhibition can be achieved either by blocking the binding of agonists to corresponding TLRs or inhibiting the intracellular signaling of the TLR pathways.

The use of a novel MyD88 inhibitor, TJ-M2010-5 in a fully MHC-mismatched murine model inhibited the LPS-stimulated activation of dendritic cells and the priming of donor allogeneic $\mathrm{T}$ cell proliferation (18). Administration of the inhibitor ameliorated the inflammatory environment, increased tissue repair in GvHD target organs and suppressed lethal GvHD. Administration of an IRAK-4 inhibitor also ameliorated GvHD in a mouse model of allo-SCT (19). In this model, MyD88 in donor T cells was not essential for graft-versus-leukemia (GvL) effects. There are other well-established medications that have been repurposed in cGvHD because of their effects on TLR signaling including statins, which decrease TLR4 expression and downstream signaling $(20,21)$ and hydroxychloroquine, an inhibitor of TLR9 signaling (22). Any strategy to block TLR signaling pathways incur significant risk, particularly during post-transplant immune reconstitution as TLR-mediated inflammation functions to protect the host against infection.

Another major part of the innate immune response, the complement system, is also implicated in cGvHD. The complement system is composed of a number of diverse signaling pathways that causes specific plasma proteins to react with one another to generate: 1) activated complement proteins that bind pathogens triggering opsonization by phagocytes, 2) fragments of some complement proteins that serve as chemoattractants and 3) membrane attack complexes that damage bacteria by creating pores in the outer bacterial membrane. All the pathways merge at the proteolytic cleavage of C3 to generate a larger fragment, C3b, that marks a target for opsonization, and a small one, $\mathrm{C} 3 \mathrm{a}$, which serves as an anaphylatoxin which triggers the release of inflammatory mediators from nearby cells. Subsequent cleavage of another complement protein, $\mathrm{C} 5$, results in $\mathrm{C} 5 \mathrm{a}$, which is also an anaphylatoxin and chemotactic factor, and $\mathrm{C} 5 \mathrm{~b}$ which initiates formation of the membrane attack complex (23). The anaphylatoxins $\mathrm{C} 3 \mathrm{a}$ and $\mathrm{C} 5 \mathrm{a}$ exert their biological function by binding to their cognate $\mathrm{G}$ protein-coupled receptors $\mathrm{C} 3 \mathrm{aR}$ and $\mathrm{C} 5 \mathrm{aR}$ on cells of the innate and adaptive immune system.

Human C3 deficiency is associated with impairments in dendritic cell maturation suggesting complement activation could play a role in the dendritic cell regulation of GvHD in first acute phase of inflammation (24). The generation of C3 and C5 complement proteins during complement activation has previously been implicated in the pathogenesis of GvHD. Expression of $\mathrm{C} 3 \mathrm{aR}$ and $\mathrm{C} 5 \mathrm{aR}$ on donor $\mathrm{T}$ cells is essential for GVHD development after HCT (25). Reduced GvHD in C3deficient mice is associated with decreased donor Th1/Th17 differentiation (26). C3aR/C5aR-mediated signaling directly induces secretion of IFN- $\gamma$ and IL- 2 from T cells driving Th1/ Th17 differentiation and suppressing Treg generation $(27,28)$. $\mathrm{C} 3 \mathrm{aR} / \mathrm{C} 5 \mathrm{aR}$ signaling suppresses lethal mitophagy in dendritic cells after HCT. Blockade of C3aR/C5aR activation significantly enhanced mitophagy in recipient dendritic cells which correlated with improved GvHD outcomes and the studies also showed that treatment with $\mathrm{C} 3 \mathrm{aR} / \mathrm{C} 5 \mathrm{aR}$ antagonists effectively separated GvHD and GvL responses making it a promising therapeutic approach for GvHD treatment especially in malignant diseases dependent on the GVL effect $(29,30)$.

In the post-allo-HCT setting, complement inhibitors such as eculizumab, (anti-C5 monoclonal antibody), narsoplimab (IgG-4 monoclonal antibody that inhibits the effector enzyme MASP-2 of the lectin complement pathway), and coversin (C5 inhibitor) have already been used in the treatment of transplant-associated thrombotic microangiopathy (TA-TMA) (31-33). It is possible that these therapies could be used as prophylaxis for cGvHD.

Targeting these innate pathways appears promising as they would ideally interrupt the early inflammatory cascade underlying cGvHD development while preserving the GvL effect.

A potential issue would be the timing of these interventions as they target the early stages of $\mathrm{cGvHD}$ which are difficult to appreciate clinically and maybe better served as prophylactic agents against GvHD or used in specific patients early post-HCT with predictive biomarkers (34).

\section{T CELL IMMUNE DYSREGULATION}

Ongoing damage to epithelial and connective tissue releases DAMPs that activate cells of the innate immune system such as dendritic cells triggering the release of IFN $\alpha$, IL-1 $\beta$, TNF $\alpha$ and IL6. This inflammatory cytokine profile induces Th1/Th17 differentiation and subsequent recruitment to the injured tissue. They are activated by APCs and continue the cycle of tissue damage. Dysfunctional thymic negative selection frees alloreactive $\mathrm{T}$ cells targeting host antigens that continually feed this vicious cycle leading to chronic tissue inflammation. This part of the review will focus on two key elements of this pathological process: 1) loss of thymic negative selection and 2) skewing of $T$ cell 
repertoire toward Th1/Th17 lineages at the expense of regulatory $\mathrm{T}$ cells. Both of these biological processes have parallels with monogenic immune disorders that provide insights into pathology and the basis for existing and potential new therapies.

\section{Loss of T Cell Thymic Selection}

Early after HCT, mature donor alloreactive T cells transferred with the allograft are activated by host APCs and mediate direct tissue destruction. In particular, thymic epithelial cells are damaged leading to release of self-reactive $\mathrm{T}$ cells. Severe histopathological damage to the thymus is a feature of aGvHD and plays a prominent role in the second phase of cGvHD. Using murine models of allogeneic HCT it has previously been shown that donor $\mathrm{T}$ cells can damage primary lymphoid tissue including the thymus. Thymic aGvHD impaired the compartment of medullary thymic epithelial cells (mTEC) that express the autoimmune regulator (AIRE) $(35,36)$. Loss of AIRE + mTEC led to a failure to clonally delete self-reactive $\mathrm{T}$ cells. This is likely caused by the decreased heterogeneity of tissue specific auto-antigens from cGVHD target organs presented by thymic mTEC cells in order to select functional but tolerant $\mathrm{T}$ cells. Accordingly, donor-derived $\mathrm{T}$ cells possessing cGvHD antigen reactivity escape deletion and expand. This loss of thymic negative selection is further exacerbated by the physiologic process of age-related thymic atrophy/involution (37). This pool of self-reactive $\mathrm{T}$ cells is under constant homeostatic pressure to expand due to overall lymphopenia in GvHD caused by the dysfunction of the peripheral niches essential for the survival of naïve T cells (38).

The AIRE gene is mutated in autoimmune polyendocrinopathycandidiasis-ectodermal dystrophy (APECED), a rare monogenic recessive disorder characterized by a variety of autoimmune diseases that target endocrine organs, liver, intestine and skin (39). This is caused by immune reactions against an assortment of autoantigens (40). Murine studies suggest that AIRE promotes ectopic transcription of self-antigens in mTECs and therefore important for negative selection of autoreactive $\mathrm{T}$ cells or in the case post-HCT, alloreactive T cells (41). All patients with APECED also have neutralizing antibodies against type I interferons and they are present before the development of autoimmune conditions (42). Antibodies to IFN $\alpha$ have also been recognized as an autoantibody that develops after allogeneic BMT in association with cGvHD $(43,44)$. Lastly, APECED patients also have a decrease in the regulatory $\mathrm{T}$ cell population (45) similar to patients with $\mathrm{cGvHD}$.

It is unclear whether thymic transplantation, which has been used successfully in the treatment of differentiative thymic disorder related to FOXN1 mutations (46), would alter the process of negative selection by the thymus. The transplantation of recipient-type thymus at 4 weeks post-BMT in an established chronic GvHD model prevented the development of cGvHD and increased survival (47). Perhaps in the future it will be possible to generate mTECs from recipients, for example through the use of induced pluripotent stem cells, prior to HCT that can be used as prophylactic treatment postHCT to support normal T cell development (48).
Another potential therapeutic target is preventing the trafficking of alloreactive $\mathrm{T}$ cells to the thymus in the early stages post-HCT thereby limiting damage to the thymus thus preserving tolerance mechanisms. This same principle could be applied to the trafficking of pathogenic $\mathrm{T}$ cells to target organs and ideally preserving trafficking of regulatory $\mathrm{T}$ cells. Sphingosine 1-phosphate (S1P) is a sphingosine containing lipid intermediate obtained from ceramide that plays a key role in lymphocyte migration through concentration gradients and binding and activation of G-protein-coupled receptors known as S1P receptors (S1PR1) (49). It has been shown that prophylactic, not therapeutic, administration of a S1PR agonist reduced donor $\mathrm{T}$ cell migration to the host thymus, thus significantly attenuating thymic aGvHD in murine model of unconditioned recipients of haploidentical donor $\mathrm{T}$ cells (50). This approach was successfully used in a patient with severe CNS GVHD (51).

\section{Skewing of T-Cell Repertoire During Chronic GvHD Development}

The acute inflammation of the first phase of cGvHD creates an environment that favors excessive pro-inflammatory Th17 cells over regulatory $\mathrm{T}$ cells that suppress inflammation. The development of $\mathrm{cGvHD}$ has been shown to be associated with a dynamic imbalance that favors the production, expansion, and persistence of effector $\mathrm{T}$ cells, in particular Th17 cells driven by BCL2 expression over CD4 regulatory T cells (52). Patients with active cGvHD had a significantly lower frequency of circulating $\mathrm{T}$ follicular helper cells (cTFH) compared with patients without cGvHD. This was associated with higher CXCL13 plasma levels suggesting increased homing of TFH to secondary lymphoid organs. The cTFH phenotype was skewed toward a highly activated profile with predominance of Th2/Th17 subsets and demonstrated increased functional ability to promote $B$ cell immunoglobulin secretion and maturation (53). Again their survival was preferentially promoted by BCL- 2 .

The creation of this immune imbalance in patients with active cGvHD lends itself to potential therapies either previously used in PIDs associated with $\mathrm{T}$ cell disorders or provides information about which gene products should be targeted to create an effect that mimics the PID phenotype; if cGvHD is associated with elevated Th17 cells then we should target affected proteins/ pathways in monogenic diseases associated with loss of Th17 cells.

The potential impact of current therapies and new avenues of treatment are discussed in the context of known PIDs with abnormal T cell homeostasis.

\section{Strategies to Increase the Number of Regulatory T Cells}

The prototypical genetic autoimmune disease involving Tregs is Immune dysregulation, polyendocrinopathy, enteropathy, Xlinked (IPEX) syndrome which is caused by mutations in the FOXP3 gene and characterized by markedly decreased or absent FOXP3+ Tregs (54). Many other primary immunodeficiencies with prevailing lymphoproliferation, such as LPS-responsive beige-like anchor protein (LRBA) deficiency and cytotoxic $\mathrm{T}$ 
lymphocyte antigen-4 (CTLA-4) haploinsufficiency, are also associated with decreased or dysregulation of Tregs $(55,56)$.

Rapamycin is a small molecule inhibitor of mechanistic target of rapamycin (mTOR) that selectively inhibits effector $\mathrm{T}$ cell proliferation while sparing rapamycin-resistant Treg cells thereby supporting the relevant expansion and function of Treg cells (57). Rapamycin has significant clinical benefits in patients with IPEX syndrome (58) and has previously shown efficacy as a cGvHD therapy $(59,60)$.

Abatacept (CTLA4-Ig) is a fusion protein consisting of an IgG1 Fc domain fused to the CTLA-4 extracellular domain that has successfully been used to control autoimmune inflammation and interstitial lung disease in patients with CTLA-4 haploinsufficiency and LRBA deficiency $(61,62)$. In a phase I clinical trial, abatacept resulted in a clinical response in $44 \%$ of patients with steroid-refractory cGvHD with both decreased prednisone use and T cell PD-1 expression in responders (63).

Inhibition of lysosomal degradation via chloroquine/ hydroxychloroquine rescued CTLA4 expression in LRBA deficient cells in vitro and improved lymphoproliferative lung pathology in a patient with LRBA mutation in vivo (64) and long term outcome of patients with LRBA deficiency (65). A phase II trial of hydroxychloroquine in patients with steroid-resistant or steroid-dependent cGvHD resulted in a 53\% response rate and all responders tolerated a $>50 \%$ reduction in their steroid dose while receiving hydroxychloroquine (66).

IL-2 is a critical cytokine for the maintenance and function of FOXP3+ Treg cells. High CD25 expression confers to Treg cells the ability to respond to low doses of IL-2, whereas effector T cells require higher IL-2 concentrations to support their proliferation. Patients with Wiskott-Aldrich syndrome who received low dose IL-2 therapy had statistically significant increase in platelet counts, a trend toward higher T, B, and NK cell numbers and higher $\mathrm{T}$ regulatory cell percentages (67). Low dose IL-2 has been shown to provide durable clinical improvement in active cGvHD and extended therapy is welltolerated (68).

It still remains controversial as to whether extracorporeal photopheresis (ECP) has a clinically significant effect on the number and function of Tregs in cGvHD (69-71).

Multiple studies have demonstrated that developing mixed chimerism post-HCT in non-malignant disease is associated with a lower incidence of aGvHD and cGvHD and among patients with mixed chimerism, cGvHD is associated with a more frequent evolution toward complete chimerism (72). The proportion of Treg cells is increased in patients with mixed chimerism after SCT and acts to suppress the alloreactive immune response (73). In non-malignant diseases, especially those undergoing reduced intensity conditioning resulting in dynamic chimera states, interventions to increase Tregs may stabilize mixed chimerism and lead to lower rates of cGvHD.

Lastly, the Infusion of donor-specific or third-party regulatory $\mathrm{T}$ cells have been tested in patients with steroidrefractory or dependent cGvHD. A phase I trial utilizing donor derived Tregs enriched by CD25+ immunomagnetic selection from a non-mobilized peripheral blood apheresis product and purified by high speed flow cytometry demonstrated feasibility, safety and tolerability with encouraging preliminary clinical responses with a single infusion of cells (74). Patients have also been treated with umbilical cord blood derived regulatory $\mathrm{T}$ cells (75).

\section{Targeting the Th17 Subset}

Autosomal dominant hyper-IgE syndrome (AD-HIES), formerly known as Job syndrome, caused by loss of function mutations in STAT3, is associated with impaired Th17 development (76). Th17 cell development is directed by multiple cytokines, including IL-1 $\beta$, IL-6, TGF- $\beta$, IL-21 and IL-23 which leads to activation of the transcription factors STAT3 and interferon regulatory factor 4 and subsequent expression of retinoic acidrelated orphan receptor (ROR)yt. It has been shown that oral administration of the selective ROCK2 inhibitor KD025 to healthy subjects or rheumatoid arthritis patients attenuates the ability of T cells to secrete IL-17 in response to stimulation ex vivo via a STAT3-dependent mechanism. ROCK2 inhibition significantly diminished STAT3 phosphorylation and binding to IL-17 and IL-21 promoters and reduced interferon regulatory factor 4 and nuclear hormone RORyt protein levels in T cells derived from healthy subjects or rheumatoid arthritis patients. Simultaneously, KD025 also promoted the suppressive function of regulatory $\mathrm{T}$ cells through up-regulation of STAT5 phosphorylation (77). KD025 has been shown to ameliorate cGvHD in multiple murine models and inhibit the secretion of IL-21, IL-17 and interferon y along with decreasing phosphorylated STAT3 and reduced protein expression of interferon regulatory factor 4 and B-cell lymphoma (BCL6) in human peripheral blood mononuclear cells purified from active cGvHD patients (78).

IL-6 is a proinflammatory cytokine that activates the STAT3 signaling cascade and promotes Th17 differentiation. Tocilizumab, the monoclonal antibody against the IL- 6 receptor, has been used to treat STAT3 gain of function disease (79). Tocilizumab appears to be a promising treatment option in advanced $c G v H D$ but further evaluation within a phase II trial is required (80).

Inherited IL-12/23 receptor beta 1 (IL-12/23R $\beta 1$ ) and IL-12/ 23 cytokine p40 subunit deficiency are rare primary immunodeficiencies associated with impaired generation of IL17 producing cells (81). Anti-p40 treatment attenuated the severity of sclerodermatous cGvHD in a murine model (82). Ustekinumab, a human IL-12 and IL-23 antagonist, delivered by subcutaneous injection on day -1 and day +20 after peripheral blood mobilized hematopoietic stem transplantation from HLAmatched sibling or unrelated donors significantly improved overall survival and National Institute of Health (NIH) moderate/severe cGvHD-free, relapse-free survival (83). It has not yet been tested in patients with existing cGvHD.

Pirfenidone has been shown to inhibit IL-17A facilitated macrophage infiltration in a mouse model of cGvHD lung disease. In addition, pirfenidone significantly reduced the percentage of IL-17a-producing $\mathrm{CD} 4+\mathrm{T}$ cells but did not affect the percentage of Tregs (84). 


\section{TARGETING METABOLIC REPROGRAMMING AS A POTENTIAL THERAPEUTIC STRATEGY}

A number of dysregulated metabolic pathways have previously been identified in PIDs and in turn congenital defects in metabolism are often associated with immune defects. Targeting these pathways in cGvHD offers new avenues of potential therapy.

It has been shown that glycolysis is required for optimal function of alloantigen-activated T cells and induction of GVHD. $\mathrm{T}$ cells switch from fatty acid $\beta$-oxidation and pyruvate oxidation via the tricarboxylic (TCA) cycle to aerobic glycolysis. Inhibition of glycolysis through specifically targeting mTORC1 or PFKFB3 ameliorated GVHD in a preclinical BMT model (85).

Glut1 deficiency selectively impairs metabolism and function of thymocytes and effector CD4 T cells while sparing Treg cells (86). Allo-reactive Glut1-deficient T cells have dramatically decreased ability to induce lethal GvHD due to reduced IL17 production.

Congenital deficiency of the adipocyte hormone leptin is associated with reduced numbers of circulating $\mathrm{CD} 4+\mathrm{T}$ cells and impaired $\mathrm{T}$ cell proliferation and cytokine release (87). In contrast, increased serum leptin concentrations may contribute to $\mathrm{T}$ cell activation during development of $\mathrm{cGvHD}$ (88).

There is literature that shows that by simply inhibiting transamination in differentiating $\mathrm{T}$ cells, Th17 cell fate can be epigenetically redirected toward the Treg lineage. A recent study identified a compound, (aminooxy)acetic acid (AOA), that is able to reprogram differentiating Th17 cells into Foxp3expressing iTreg cells by inhibiting the activity of glutamateoxaloacetate transaminase (GOT1) (89). Another group were able to show that transiently inhibiting glutamine metabolism by targeting glutaminase activity lead to impaired differentiation of Th17 cells and increased Th1 and CTL effector cell function (90).

Selectively targeting metabolic pathways in order to alter the balance of TH17/Treg cells may represent a novel strategy to treat chronic GvHD.

\section{THE ROLE OF B CELL MEDIATED AUTOIMMUNITY}

Chronic GvHD has many clinical, histological and serological manifestations that resemble the autoimmunity and dysgammaglobulinemia associated with primary B-cell related immunodeficiencies. Multiple lines of evidence point to an important role for B cells in the pathogenesis of cGvHD. Antibodies to both alloantigens and nonpolymorphic autoantigens are frequently associated with $\mathrm{cGvHD}(91,92)$. Stimulatory antibodies to the platelet-derived growth factor (PDGF) receptor (PDGFR) are selectively found in patients with extensive $\mathrm{cGvHD}$ and activate the generation of reactive oxygen species which stimulates type 1 collagen gene expression suggesting a role in the development of fibrosis (93). Allogeneic
HY antibodies detected at 3 months after female to male HCT predict cGvHD in humans (94). B cells facilitate autoimmunity not just by secreting host-reactive antibodies, but also by secreting proinflammatory cytokines and by presenting autoantigens to $\mathrm{T}$ cells (95). Conversely, an impaired ability of $B$ cells to produce IL-10 was found in patients with active cGvHD (96). Perhaps the best evidence for B cell involvement is the success of rituximab, a chimeric anti-CD20 monoclonal antibody, in corticosteroid-free primary treatment of cGvHD (97-99).

The emergence and persistence of host-reactive B cells in cGvHD results from acquired failures in tolerance mechanisms. Central B cell tolerance is compromised in cGvHD due to altered $\mathrm{B}$ cell signalling that affects the negative and positive selection of $\mathrm{B}$ cells during development, skewing the emerging $\mathrm{B}$ cell repertoire towards a host or self-reactivity. Autoantibody production may also occur due to disturbed $\mathrm{T}$ cell- $\mathrm{B}$ cell interaction and regulation (100). The highest rate of autoimmune cytopenias following HCT are reported in children undergoing HCT for non-malignant indications with anti-thymocyte globulin (ATG) or alemtuzumab-containing conditioning regimens (101).

The most important driver of immature bone marrow $\mathrm{B}$ cell tolerance is $\mathrm{B}$-cell receptor (BCR) signaling after encountering self-antigens. Developmental fate is based on strength and location of BCR engagement, the form of self-antigen and synergy with other co-receptor signals (102). It is clear there are intrinsic and extrinsic factors that can skew this process and overcome other processes that would normally remove autoreactive B cells. Two of the most critical signaling pathways that integrate with $\mathrm{BCR}$ signaling in $\mathrm{B}$ cell survival and tolerance are Toll-like receptor (TLR) and B cell-activating factor receptor (BAFFR) signaling.

TLR activation appears to contribute to both the negative and positive selection of autoreactive $\mathrm{B}$ cells depending on the developmental stage based on observations in PID patients. Patients who lack MyD88 or IRAK-4 exhibit defects in central and peripheral $\mathrm{B}$ cell tolerance, implicating TLR-dependent innate signaling pathways in negative selection of immature autoreactive B cell clones $(103,104)$. In contrast, there is evidence for TLR signaling promoting transitional B cell positive selection in patients with Wiskott-Aldrich syndrome (WAS). There is enhanced signaling downstream of both the BCR and TLRs in B cells from WAS patients that promotes the positive selection of autoreactive transitional B cells $(105,106)$.

$B$ cell activating factor (BAFF) plays a fundamental role in the survival and differentiation of $B$ cells (107). Its' principal cognate receptor in early $\mathrm{B}$ cell development is the BAFF receptor (BAFF$\mathrm{R})$. Without BAFF-R, B-cell development is arrested at the stage of transitional $B$ cells and the numbers of all subsequent $B$ cell stages are severely reduced (108). Increased BAFF levels rescue low-affinity self-reactive transitional B cells by co-opting BCR signaling through phosphorylation of proximal BCR signaling components such as spleen tyrosine kinase (Syk) (109). BAFF also enhances TLR7/9 expression on B cells and TLR-mediated production of autoantibodies (110). In turn, TLR signaling 
promotes BAFF receptor expression creating a positive feedback loop (111). Murine models of B cell autoimmunity suggest that excess BAFF and a reduced pool of naïve B cells are both necessary to promote the survival of autoreactive B cells (112, 113). BAFF has also been shown to selectively enhance the survival of plasmablasts which would promote the subsequent production of host-reactive antibodies (114).

Chronic GvHD is associated with reduced transitional and naïve B cell counts (115), elevated levels of sBAFF (116) and Syk hyperresponsiveness in B cells.

Belimumab, a fully human monoclonal IgG1 $\lambda$ anti-BAFF antibody, is currently being tested as prophylaxis against chronic GvHD in a phase 1 trial (NCT03207958). Inhibition of Syk with fostamatinib in mice with established cGvHD with bronchiolitis obliterans was able to reverse disease. It also decreased the frequency of GCs and expression of the activation costimulatory molecules CD80 and CD86 in CD11c + cells in vivo. Most importantly, human cGvHD B cells had increased death when treated with fostamatinib (117). Inhibiting Syk kinase activity abrogates the BCR-driven ex vivo proliferative and survival advantage of human cGvHD B cells (118).

Another example of a PID with a B cell specific break in selftolerance are patients with gain-of-function mutations in PIK3CD, encoding the p1 $10 \delta$ catalytic subunit of phosphoinositide 3-kinase (PI3K), who present with production of germline autoreactive IgM antibodies (119). PI3K expression has been shown to be increased in $\mathrm{cGvHD}$ patients (120). The effective treatment of mice with active $c G v H D$ with PI3K-specific inhibitors support future clinical trials of approved PI3K inhibitors for cGvHD therapy in humans (121).

In humans, central B cell tolerance checkpoints are also abrogated in the absence of Bruton's tyrosine kinase (BTK), an essential BCR signaling component (122). Patients suffering from X-linked agammaglobulinemia, caused by loss of function mutations in the BTK gene, have a severe decrease of peripheral $B$ cells and serum immunoglobulin. B cell differentiation is severely affected at the pro- to pre-B transition but the few $\mathrm{B}$ cells that do develop are paradoxically enriched in autoreactive clones. The use of antileukemic drugs that inhibit Btk signaling to promote apoptosis of malignant B cells, especially in chronic lymphocytic leukemia, theoretically may also affect $B$ cell selection by interfering with normal BCR signaling leading to the release of autoreactive B cells. Autoimmune cytopenias have been observed in patients with chronic lymphocytic leukemia treated with ibrutinib $(123,124)$.

Treatment of patients with active cGvHD with inadequate response to corticosteroid-containing therapies with ibrutinib, a BTK inhibitor, in a phase II clinical trial resulted in clinically meaningful responses with acceptable safety leading it to become the only FDA-approved second-line therapy for steroid-resistant cGvHD (125, 126).

Targeting Btk in cGvHD patients with ibrutinib also highlights the potential for phenotypic differences between germline presentations and the effects of an imperfect inhibitor. In addition to its critical role in B cell development, BTK is important for collagen signaling via the collagen receptor glycoprotein VI (GPVI) in platelets (127). Ibrutinib has been reported to increase rates of major hemorrhage through selective inhibition of platelet signaling and functions downstream of the collagen receptor GPVI and strongly affects firm platelet adhesion on von Willebrand factor (VWF) under arterial flow (128). In contrast to ibrutinib-treated subjects, patients with XLA do not bleed excessively. The risk of bleeding is attributed to off-target effects of ibrutinib on several other intracellular molecules important for platelet signaling including $\mathrm{Tec}$, another kinase of the Tec family of proteintyrosine kinases that includes Btk (129). Ibrutinib can also affect $\mathrm{T}$ cells due to the off-target inhibition of IL-2 inducible T cell kinase (ITK) with shares significant homology with BTK. Ibrutinib treatment in chronic lymphocytic leukemia (CLL) patients markedly increases CD4+ and CD8+ T cell numbers, decreases the Treg/CD4+ $\mathrm{T}$ cell ratio and reduced $\mathrm{PD}-1$ and CTLA-4 expression in T cells (130). It remains unclear if the efficacy of ibrutinib in targeting B cells in cGvHD will be offset by changes in $\mathrm{T}$ cell populations, significant risk of bleeding and potential flares of autoimmunity.

\section{FIBROTIC END STAGES OF CGVHD}

Fibrosis represents the end stage of the chronic inflammation that occurs in cGvHD and once fixed is poorly amenable to any known therapies. It is thought to result from an aberrant woundhealing process driven by M2-polarized macrophages that in turn produce transforming growth factor- $\beta$ (TGF- $\beta$ ) and platelet-derived growth factor- $\alpha$ (PDGF- $\alpha$ ) leading to the activation of collagen-producing fibroblasts and myofibroblasts partly through sonic hedgehog signaling (131). The prominent role of TGF- $\beta$, PDGF- $\alpha$ and sonic hedgehog (SHH) in stimulating fibroblasts has led to the use of tyrosine kinase inhibitors such as imatinib mesylate and the Hedgehog pathway inhibitor sonidegib in the treatment of sclerotic cGvHD (132-134).

Even though there is a lack of a strong association between primary immune disorders and fibrosis, sclerotic or sclerodermalike changes, there are other rare monogenic diseases that have already or may provide new therapeutic avenues. Mutations in MMP2, an antifibrotic metalloproteinase, may result in scleroderma-like skin thickening (135). Patients post-HCT with low levels of plasma MMP-2 were more likely to develop sclerotic cGvHD (136). Narrowband ultraviolet-B light therapy, which is known to increase the level of dermal MMP-2 (137), has successfully been used to treat sclerotic cGvHD (138).

Mutations in fibrillin-1 cause stiff skin syndrome (SSS), an autosomal dominant congenital form of scleroderma (139). These mutations all localize to the domain in fibrillin- 1 that harbours a motif needed to mediate cell-matric interactions by binding cell-surface integrins. Aggressive skin fibrosis in mouse lines harbouring analogous mutations was prevented by integrinmodulating therapies and reversed by antagonism of TGF- $\beta$ (140). Perhaps there is an role for integrin inhibition in the prophylaxis or treatment of $\mathrm{cGvHD}$ analogous to the use of 
natalizumab (monoclonal antibody against $\alpha 4$-integrin) and vedolizumab ( $\alpha 4 \beta 7$ inhibitor) in the treatment of steroid refractory aGvHD of the gut $(141,142)$.

\section{CONCLUDING REMARKS}

Immune disorders due to single gene defects offer invaluable insights into understanding the immune dysregulation that occurs during all three phases of cGvHD development. One of the issues that clinicians continue to struggle with is the timing of interventions either as prophylaxis or treatment and the ideal therapy or combination of therapies depending on the specific clinical $\mathrm{CGvHD}$ phenotype. It is clear that by the time many of the clinical manifestations of $\mathrm{cGvHD}$, in particular fibrotic and

\section{REFERENCES}

1. Ritz J, Socie G. Current issues in chronic graft-versus-host disease. Blood. (2014) 124(3):374-84. doi: 10.1182/blood-2014-01-514752

2. Wingard JR, Majhail NS, Brazauskas R, Wang Z, Sobocinski KA, Jacobsohn D, et al. Long-term survival and late deaths after allogeneic hematopoietic cell transplantation. J Clin Oncol (2011) 29(16):2230-9. doi: 10.1200/ JCO.2010.33.7212

3. Jagasia MH, Greinix HT, Arora M, Williams KM, Wolff D, Cowen EW, et al. National institutes of health consensus development project on criteria for clinical trials in chronic graft-versus-host disease: I. The 2014 diagnosis and staging working group report. Biol Blood Marrow Transplant (2015) 21 (3):389-401. doi: 10.1016/j.bbmt.2015.02.025

4. Baird K, Cooke K, Schultz KR. Chronic graft versus host disease (GVHD) in children. Pediatr Clin North Am (2010) 57(1):297-322. doi: 10.1016/ j.pcl.2009.11.003

5. Cooke KR, Luznik L, Sarantopoulos S, Hakim FT, Jagasia M, Fowler DH, et al. The biology of chronic graft-versus-host disease: a task force report from the national institutes of health consensus development project on criteria for clinical trials in chronic graft-versus-host disease. Biol Blood Marrow Transplant (2017) 23(2):211-34. doi: 10.1016/j.bbmt. 2016.09.023

6. Tangye SG, Al-Herz W, Bousfiha A, Chatila T, Cunningham-Rundles C, Etzioni A, et al. Human inborn errors of immunity: 2019 update on the classification from the international union of immunological societies expert committee. J Clin Immunol (2020) 40(1):24-64. doi: 10.1007/s10875-01900737-x

7. Brinkman RR, Dube MP, Rouleau GA, Rouleau GA, Orr AC, Samuels ME. Human monogenic disorders - a source of novel drug targets. Nat Rev Genet (2006) 7(4):249-60. doi: 10.1038/nrg1828

8. Fredricks DN. The gut microbiota and graft-versus-host disease. J Clin Invest (2019) 129(5):1808-17. doi: 10.1172/JCI125797

9. Pellicciotta M, Rigoni R, Falcone EL, Holland SM, Villa A, Cassani B. The microbiome and immunodeficiencies: lessons from rare diseases. J Autoimmun (2019) 98:132-48. doi: 10.1016/j.jaut.2019.01.008

10. Macpherson AJ, Köller Y, McCoy KD. The bilateral responsiveness between intestinal microbes and IgA. Trends Immunol (2015) 36(8):460-70. doi: 10.1016/j.it.2015.06.006

11. Vatanen T, Kostic AD, d'Hennezel E, Siljander H, Franzosa EA, Yassour M, et al. Variation in microbiome LPS immunogenicity contributes to autoimmunity in humans. Cell (2016) 165(4):842-53. doi: 10.1016/ j.cell.2016.04.007

12. Zama D, Bossu G, Leardini D, Muratore E, Biagi E, Prete A, et al. Insights into the role of intestinal microbiota in hematopoietic stem-cell transplantation. Ther Adv Hematol (2020) 11:2040620719896961. doi: $10.1177 / 2040620719896961$ sclerotic changes, are evident many of the therapies targeting earlier phases of inflammation may be ineffective. This only reinforces the urgent need to develop predictive and prognostic biomarkers that properly identify earlier stages of the disease where interventions may be more effective.

It is clear the cGvHD is a heterogeneous disease with multiple pathogenic pathways operating simultaneously and superior treatments will only emerge from an improved understanding of disease mechanisms.

\section{AUTHOR CONTRIBUTIONS}

The author confirms being the sole contributor of this work and has approved it for publication.

13. Watts C, West MA, Zaru R. TLR signalling regulated antigen presentation in dendritic cells. Curr Opin Immunol (2010) 22(1):124-30. doi: 10.1016/ j.coi.2009.12.005

14. Weng J, Lai P, Geng S, Luo C, Wu S, Ling W, et al. Role of toll-like receptor 4 signaling in cutaneous chronic graft-versus-host disease. Clin Transplant (2015) 29(6):547-54. doi: 10.1111/ctr.12551

15. Warner N, Nunez G. MyD88: a critical adaptor protein in innate immunity signal transduction. J Immunol (2013) 190(1):3-4. doi: 10.4049/ jimmunol.1203103

16. Liu T, Zhang L, Joo D, Sun SC. NF- $\kappa B$ signaling in inflammation. Signal Transd Targ Ther (2017) 2:17023. doi: 10.1038/sigtrans.2017.23

17. Picard C, von Bernuth H, Ghandil P, Chrabieh M, Levy O, Arkwright PD, et al. Clinical features and outcomes of patients with IRAK-4 and MyD88 deficiency. Med (Baltimore) (2010) 89(6):403-25. doi: 10.1097/ MD.0b013e3181fd8ec3

18. Xing S, Zhang X, Huang X, Xie L, Jiang F, Zhou P, et al. Modulating the conformation of the TIR domain by a neoteric MyD88 inhibitor leads to the separation of GVHD from GVT. Leuk Lymphoma (2019) 60(6):1528-39. doi: 10.1080/10428194.2018.1537487

19. Matsuoka S, Hashimoto D, Kadowaki M, Ohigashi H, Hayase E, Yokoyama E, et al. Myeloid differentiation factor 88 signaling in donor $\mathrm{T}$ cells accelerates graft-versus-host disease. Haematologica (2020) 105(1):226-34. doi: 10.3324/ haematol.2018.203380

20. Methe H, Kim JO, Kofler S, Nabauer M, Weis M. Statins decrease Toll-like receptor 4 expression and downstream signaling in human CD14+ monocytes. Arterioscler Thromb Vasc Biol (2005) 25(7):1439-45. doi 10.1161/01.ATV.0000168410.44722.86

21. Rotta M, Storer BE, Storb R, Martin PJ, Flowers MED, Vernon MS, et al. Impact of recipient statin treatment on graft-versus-host disease after allogeneic hematopoietic cell transplantation. Biol Blood Marrow Transplant (2010) 16(10):1463-6. doi: 10.1016/j.bbmt.2010.05.006

22. Gilman AL, Schultz KR, Goldman FD, Sale GE, Krailo MD, Chen Z, et al. Randomized trial of hydroxychloroquine for newly diagnosed chronic graftversus-host disease in children: A children's oncology group study. Biol Blood Marrow Transplant (2012) 18(1):84-91. doi: 10.1016/ j.bbmt.2011.05.016

23. Wen L, Atkinson JP, Giclas PC. Clinical and laboratory evaluation of complement deficiency. J Allergy Clin Immunol (2004) 113(4):585-93. doi: 10.1016/j.jaci.2004.02.003

24. Ghannam A, Pernollet M, Fauquert JL, Monnier N, Ponard D, Villiers MB, et al. Human C3 deficiency associated with impairments in dendritic cell differentiation, memory B cells, and regulatory T cells. J Immunol (2008) 181 (7):5158-66. doi: 10.4049/jimmunol.181.7.5158

25. Kwan WH, Hashimoto D, Paz-Artal E, Ostrow K, Greter M, Raedler H, et al. Antigen-presenting cell-derived complement modulates graft-versus-host disease. J Clin Invest (2012) 122(6):2234-8. doi: 10.1172/JCI61019 
26. Ma Q, Li D, Nurieva R, Patenia R, Bassett R, Cao W, et al. Reduced graftversus-host disease in C3-deficient mice is associated with decreased donor Th1/Th17 differentiation. Biol Blood Marrow Transplant (2012) 18(8):117481. doi: 10.1016/j.bbmt.2012.05.014

27. Barchet W, Price JD, Cella M, Colonna M, MacMillan SK, Cobb JP, et al. Complement-induced regulatory $\mathrm{T}$ cells suppress $\mathrm{T}$-cell responses but allow for dendritic-cell maturation. Blood (2006) 107(4):1497-504. doi: 10.1182/ blood-2005-07-2951

28. Strainic MG, Liu J, Huang D, An F, Lalli PN, Muqim N, et al. Locally produced complement fragments C5a and C3a provide both costimulatory and survival signals to naïve CD4+ T cells. Immunity (2008) 28(3):425-35. doi: 10.1016/j.immuni.2008.02.001

29. Nguyen H, Alawieh A, Bastian D, Kuril S, Dai M, Daenthanasanmak A, et al. Targeting the complement alternative pathway permits graft versus leukemia activity while preventing graft versus host disease. Clin Cancer Res (2020) 26(13):3481-90. doi: 10.1158/1078-0432.CCR-19-1717

30. Nguyen H, Kuril S, Bastian D, Kim J, Zhang M, Vaena SG, et al. Complement C3a and C5a receptors promote GVHD by suppressing mitophagy in recipient dendritic cells. JCI Insight (2018) 3(24):e121697. doi: 10.1172/jci.insight.121697

31. Patriquin CJ, Kuo KHM. Eculizumab and beyond: the past, present, and future of complement therapeutics. Transfus Med Rev (2019) 33(4):256-65. doi: 10.1016/j.tmrv.2019.09.004

32. Jodele S, Dandoy CE, Lane A, Laskin BL, Teusink-Cross A, Myers KC, et al. Complement blockade for TA-TMA: lessons learned from a large pediatric cohort treated with eculizumab. Blood (2020) 135(13):1049-57. doi: 10.1182/ blood.2019004218

33. Goodship THJ, Pinto F, Weston-Davies WH, Silva J, Nishimura JI, Nunn MA, et al. Use of the complement inhibitor Coversin to treat HSCTassociated TMA. Blood Adv (2017) 1(16):1254-8. doi: 10.1182/ bloodadvances. 2016002832

34. Yu J, Storer BE, Kushekhar K, Abu Zaid M, Zhang Q, Gafken PR, et al. Biomarker panel for chronic graft-versus-host disease. J Clin Oncol (2016) 34 (22):2583-90. doi: 10.1200/JCO.2015.65.9615

35. Dertschnig S, Nusspaumer G, Ivanek R, Hauri-Hohl MM, Hollander GA, Krenger W, et al. Epithelial cytoprotection sustains ectopic expression of tissue-restricted antigens in the thymus during murine acute GVHD. Blood (2013) 122(5):837-41. doi: 10.1182/blood-2012-12-474759

36. Dertschnig S, Hauri-Hohl MM, Vollmer M, Hollander GA, Krenger W. Impaired thymic expression of tissue-restricted antigens licenses the de novo generation of autoreactive CD4+ T cells in acute GVHD. Blood (2015) 125 (17):2720-3. doi: 10.1182/blood-2014-08-597245

37. Gaballa A, Clave E, Uhlin M, Toubert A, Arruda LCM. Evaluating thymic function after human hematopoietic stem cell transplantation in the personalized medicine era. Front Immunol (2020) 11:1341. doi: 10.3389/ fimmu.2020.01341

38. Dulude G, Roy DC, Perreault C. The effect of graft-versus-host disease on T cell production and homeostasis. J Exp Med (1999) 189(9):1329-42. doi: 10.1084/jem.189.8.1329

39. Pitkanen J, Peterson P. Autoimmune regulator: from loss of function to autoimmunity. Genes Immun (2003) 4(1):12-21. doi: 10.1038/ sj.gene.6363929

40. Betterie C, Dal Pra C, Mantero F, Zanchetta R. Autoimmune adrenal insufficiency and autoimmune polyendocrine syndromes: autoantibodies, autoantigens, and their applicability in diagnosis and disease prediction. Endocr Rev (2002) 23(3):327-64. doi: 10.1210/edrv.23.3.0466

41. Arstila TP, Jarva H. Human APECED; a sick thymus syndrome? Front Immunol (2013) 4:313. doi: 10.3389/fimmu.2013.00313

42. Meloni A, Furcas M, Cetani F, Marcocci C, Falorni A, Periola R, et al. Autoantibodies against type I interferons as an additional diagnostic criteria for autoimmune polyendocrine syndrome type I. J Clin Endocrinol Metab (2008) 93(11):4389-97. doi: 10.1210/jc.2008-0935

43. Prummer O, Bunjes D, Wiesneth, Arnold R, Porzsolt F, Heimpel H, et al. High-titre interferon-alpha antibodies in a patient with chronic graft-versushost disease after allogeneic bone marrow transplantation. Bone Marrow Transplant (1994) 14(3):483-6.

44. Prummer O, Bunjes D, Wiesneth M, Hertenstein B, Arnold R, Porzsolt F, et al. Antibodies to interferon-alpha: a novel type of autoantibody occurring after allogeneic bone marrow transplantation. Bone Marrow Transplant (1996) 17(4):617-23.

45. Ryan KR, Lawson CA, Lorenzi AR, Arkwright PD, Isaacs JD, Lilic D. CD4+ CD25+ T-regulatory cells are decreased in patients with autoimmune polyendocrinopathy candidiasis ectodermal dystrophy. J Allergy Clin Immunol (2005) 116(5):1158-9. doi: 10.1016/j.jaci.2005.08.036

46. Markert ML, Marques JG, Neven B, Devlin BH, McCarthy EA, Chinn IK, et al. First use of thymus transplantation therapy for FOXN1 deficiency (nude/SCID): a report of 2 cases. Blood (2011) 117(2):688-96. doi: 10.1182/ blood-2010-06-292490

47. Agboola O, Chen J, Markert ML. Thymus transplantation for chronic graft versus host disease. J Allergy Clin Immunol (2017) 139(2):AB590. doi: 10.1016/j.jaci.2016.12.605

48. Okabe M, Ito S, Nishio N, Tanaka Y, Isobe KI. Thymic epithelial cells induced from pluripotent stem cells by a three-dimensional spheroid culture system regenerates functional T cells in nude mice. Cell Reprogr (2015) 17 (5):368-75. doi: 10.1089/cell.2015.0006

49. Tiper IV, East JE, Subrahmanyam PB, Webb TJ. Sphingosine 1-phosphate signaling impacts lymphocyte migration, inflammation and infection. Pathog Dis (2016) 74(6):ftw063. doi: 10.1093/femspd/ftw063

50. Vollmer M, Krenger W. The role of S1PR1 agonism in thymus-dependent generation of autoreactive T cells during experimental acute graft-vs.-host disease. Biol Blood Marrow Transpl (2018) 24(3):S180. doi: 10.1016/ j.bbmt.2017.12.131

51. Gauthier J, Vermersch P, Chauvet P, Varlet P, Coiteux V, Magro L, et al. Successful treatment with fingolimod of graft-versus-host disease of the central nervous system. Blood Adv (2018) 2(1):10-3. doi: 10.1182/ bloodadvances.2017011478

52. Alho AC, Kim HT, Chammas MJ, Reynolds CG, Matos TR, Forcade E, et al. Unbalanced recovery of regulatory and effector $\mathrm{T}$ cells after allogeneic stem cell transplantation contributes to chronic GvHD. Blood (2016) 127(5):64657. doi: 10.1182/blood-2015-10-672345

53. Forcade E, Kim HT, Cutler C, Wang K, Alho AC, Nikiforow S, et al. Circulating $\mathrm{T}$ follicular helper cells with increased function during chronic graft-versus-host disease. Blood (2016) 127(20):2489-97. doi: 10.1182/ blood-2015-12-688895

54. Torgerson T, Ochs HD. Immune dysregulation, polyendocrinopathy, enteropathy, X-linked: forkhead box protein 3 mutations and lack of regulatory T cells. J Allergy Clin Immunol (2007) 120(4):744-50. doi: 10.1016/j.jaci.2007.08.044

55. Gamez-Diaz L, August D, Stepensky P, Revel-Vilk S, Seidel MG, Noriko M, et al. The extended phenotype of LPS-responsive beige-like anchor protein (LRBA) deficiency. J Allergy Clin Immunol (2016) 137(1):223-30. doi: 10.1016/j.jaci.2015.09.025

56. Kuehn HS, Ouyang W, Lo B, Deenick EK, Niemela JE, Avery DT, et al. Immune dysregulation in human subjects with heterozygous germline mutations in CTLA4. Science (2014) 345(6204):1623-7. doi: 10.1126/ science. 1255904

57. Battaglia M, Stabilini A, Migliavacca B, Horejs-Hoeck J, Kaupper T, Roncarolo MG, et al. Rapamycin promotes expansion of functional CD4+ $\mathrm{CD} 25+\mathrm{FOXP} 3+$ regulatory $\mathrm{T}$ cells of both healthy subjects and type 1 diabetic patients. J Immunol (2006) 177(12):8338-47. doi: 10.4049/ jimmunol.177.12.8338

58. Barzaghi F, Hernandez LCA, Neven B, Ricci S, Yesim Kucuk Z, Bleesing JJ, et al. Long-term follow-up of IPEX syndrome patients after different therapeutic strategies: an international multicenter retrospective study. J Allergy Clin Immunol (2018) 141(3):1036-49. doi: 10.1016/j.jaci. 2017.10.041

59. Johnston LJ, Brown J, Shizuru JA, Stockerl-Goldstein KE, Stuart MJ, Blume KG, et al. Rapamycin (sirolimus) for treatment of chronic graft-versus-host disease. Biol Blood Marrow Transplant (2005) 11(1):47-55. doi: 10.1016/ j.bbmt.2004.10.004

60. Jedlickova Z, Burlakova I, Bug G, Baurmann H, Schwerdtfeger R, Schleuning M, et al. Therapy of sclerodermatous chronic graft-versus-host disease with mammalian target of rapamycin inhibitors. Biol Blood Marrow Transplant (2011) 17(5):657-63. doi: 10.1016/j.bbmt.2010.07.025

61. Schwab C, Gabrysch A, Olbrich P, Patino V, Warnatz K, Wolff D, et al. Phenotype, penetrance, and treatment of 133 cytotoxic T-lymphocyte 
antigen 4-insufficient subjects. J Allergy Clin Immunol (2018) 142(6):193246. doi: $10.1016 /$ j.jaci.2018.02.055

62. Lo B, Zhang K, Lu W, Zheng L, Zhang Q, Kanellopoulou C, et al. Patients with LRBA deficiency show CTLA4 loss and immune dysregulation responsive to abatacept therapy. Science. (2015) 349(6246):436-40. doi: 10.1126/science.aaa1663

63. Nahas MR, Soiffer RJ, Kim HT, Alyea EPIII, Arnason J, Joyce R, et al. Phase 1 clinical trial evaluating abatacept in patients with steroid-refractory chronic graft-versus-host disease. Blood (2018) 131(25):2836-45. doi: 10.1182/ blood-2017-05-780239

64. Mustillo PJ, Jordan MB. Response to hydroxychloroquine in CVID with granulomatous interstitial lung disease (GL-ILD). Clin Immunol Soc (CIS) Annu Meeting Boston MA (2016) 36(3):329.

65. Tesch VK, Abolhassani H, Shadur B, Zobel J, Mareika Y, Sharapova S, et al. Long-term outcome of LRBA deficiency in 76 patients after various treatment modalities as evaluated by the immune deficiency and dysregulation activity (IDDA) score. J Allergy Clin Immunol (2020) 145 (5):1452-63. doi: 10.1016/j.jaci.2019.12.896

66. Gilman AL, Chan KW, Mogul M, Morris C, Goldman FD, Boyer M, et al. Hydroxychloroquine for the treatment of chronic graft-versus-host disease. Biol Blood Marrow Transplant (2000) 6(3):327-34. doi: 10.1016/S1083-8791 (00)70058-9

67. Jyonouchi S, Gwafila B, Gwalani LA, Ahmad M, Moertel C, Holbert C, et al. Phase I trial of low-dose interleukin 2 therapy in patients with WiskottAldrich syndrome. Clin Immunol (2017) 179:47-53. doi: 10.1016/ j.clim.2017.02.001

68. Koreth J, Kim HT, Jones KT, Lange PB, Reynolds CG, Chammas MJ, et al. Efficacy, durability, and response predictors of low-dose interleukin-2 therapy for chronic graft-versus-host disease. Blood (2016) 128(1):130-7. doi: 10.1182/blood-2016-02-702852

69. Zhu L, Couriel DR, Chang CH. The effect of extracorporeal photopheresis on $\mathrm{T}$ cell response in chronic graft-versus-host disease. Leuk Lymphoma (2016) 57(2):376-84. doi: 10.3109/10428194.2015.1057893

70. Gandelman JS, Song DJ, Chen H, Engelhardt BG, Chen YB, Clark WB, et al. A prospective trial of extracorporeal photopheresis for chronic graft-versushost disease reveals significant disease response and no association with frequency of regulatory T cells. Biol Blood Marrow Transplant (2018) 24 (12):2373-80. doi: 10.1016/j.bbmt.2018.06.035

71. Denney HA, Whittle RJ, Lai J, Jacques RM, Taylor PC, et al. Regulatory T cells in chronic graft-versus-host disease after extracorporeal photopheresis: correlation with skin and global organ responses, and ability to taper steroids. Transplantation (2017) 101(1):204-11. doi: 10.1097/ TP. 0000000000001165

72. Faraci M, Bagnasco F, Leoni M, Giardino S, Terranova P, Subissi L, et al. Evaluation of chimerism dynamics after allogeneic hematopoietic stem cell transplantation in children with nonmalignant diseases. Biol Blood Marrow Transplant (2018) 24(5):1088-93. doi: 10.1016/j.bbmt.2017.12.801

73. Kinsella FAM, Zuo J, Inman CF, Pearce H, Maggs L, Eldershaw SE, et al. Mixed chimerism established by hematopoietic stem cell transplantation is maintained by host and donor T regulatory cells. Blood Adv (2019) 3(5):73443. doi: 10.1182/bloodadvances. 2018025502

74. Johnston L, Armstrong R, Baker J, Sahaf B, Otani J, Tate K, et al. A phase I study of donor regulatory $\mathrm{T}$ cells as treatment for steroid dependent/ refractory chronic graft versus disease. Blood (2016) 128(22):385. doi: 10.1182/blood.V128.22.385.385

75. Brunstein CG, Miller JS, McKenna DH, Hippen KL, DeFor TE, Sumstad D, et al. Umbilical cord blood-derived T regulatory cells to prevent GVHD: kinetics, toxicity profile, and clinical effect. Blood (2016) 127(8):1044-51. doi: 10.1182/blood-2015-06-653667

76. McDonald DR. Th17 deficiency in human disease. J Allergy Clin Immunol (2012) 129(6):1429-35. doi: 10.1016/j.jaci.2012.03.034

77. Zanin-Zhorov A, Weiss JM, Nyuydzefe MS, Chen W, Scher JU, Mo R, et al. Selective oral ROCK2 inhibitor down-regulates IL-21 and IL-17 secretion in human T cells via STAT3-dependent mechanism. Proc Natl Acad Sci USA (2014) 111(47):16814-9. doi: 10.1073/pnas.1414189111

78. Flynn R, Paz K, Du J, Reichenbach DK, Taylor PA, et al. Targeted Rhoassociated kinase 2 inhibition suppresses murine and human chronic GVHD through a Stat3-dependent mechanism. Blood (2016) 127(17):2144-54. doi: 10.1182/blood-2015-10-678706

79. Khoury T, Molho-Pessach V, Ramot Y, Ayman AR, Elpeleg O, Berkman N, et al. Tocilizumab promotes regulatory T-cell alleviation in STAT3 gain-offunction-associated multi-organ autoimmune syndrome. Clin Ther (2017) 39(2):444-9. doi: 10.1016/j.clinthera.2017.01.004

80. Kattner AS, Holler E, Holler B, Klobuch S, Weber D, Martinovic D, et al. IL6-receptor antibody tocilizumab as salvage therapy in severe chronic graftversus-host disease after allogeneic hematopoietic stem cell transplantation: a retrospective analysis. Ann Hematol (2020) 99(4):847-53. doi: 10.1007/ s00277-020-03968-w

81. De Beaucoudrey L, Puel A, Filipe-Santos O, Cobat A, Ghandil P, Chrabieh M, et al. Mutations in STAT3 and IL12RB1 impair the development of human IL17-producing T cells. J Exp Med (2008) 205(7):1543-50. doi: 10.1084/ jem.20080321

82. Wu Y, Bastian D, Schutt S, Nguyen H, Fu J, Heinrichs J, et al. Essential role of interleukin-12/23p40 in the development of graft-versus-host disease in mice. Biol Blood Marrow Transplant (2015) 21(7):1195-204. doi: 10.1016/ j.bbmt.2015.03.016

83. Pidala J, Beato F, Kim J, Betts B, Jim H, Sagatys E, et al. In vivo IL-12/IL23 p40 neutralization blocks Th1/Th17 response after allogeneic hematopoietic cell transplantation. Haematologica (2018) 103(3):531-9. doi: 10.3324/haematol.2017.171199

84. Du J, Paz K, Flynn R, Vulic A, Robinson TM, Lineburg KE, et al. Pirfenidone ameliorates murine chronic GVHD through inhibition of macrophage infiltration and TGF- $\beta$ production. Blood (2017) 129(18):2570-80. doi: 10.1182/blood-2017-01-758854

85. Nguyen HD, Chatterjee S, Haarberg KMK, Wu Y, Bastian D, Heinrichs J, et al. Metabolic reprogramming of alloantigen-activated $\mathrm{T}$ cells after hematopoietic cell transplantation. J Clin Invest (2016) 126(4):1337-52. doi: $10.1172 /$ JCI82587

86. Macintyre AN, Gerriets VA, Nichols AG, Michalek RD, Rudolph MC, Deoliveira D, et al. The glucose transporter Glut1 is selectively essential for CD4 T cell activation and effector function. Cell Metab (2014) 20(1):6172. doi: 10.1016/j.cmet.2014.05.004

87. Farooqi IS, Matarese G, Lord GM, eKeogh JM, Lawrence E, Agwu C, et al. Beneficial effects of leptin on obesity, $\mathrm{T}$ cell hyporesponsiveness, and neuroendocrine/metabolic dysfunction of human congenital leptin deficiency. J Clin Invest (2002) 110(8):1093-103. doi: 10.1172/JCI0215693

88. Tauchmanova L, Matarese G, Carella C, De Rosa G, Serio B, Ricci P, et al. High serum leptin in patients with chronic graft-versus-host disease after hematopoietic stem cell transplantation. Transplantation (2004) 78(9):137683. doi: 10.1097/01.TP.0000140485.20848.B7

89. Xu T, Stewart KM, Wang X, Liu K, Xie M, Ruy JK, et al. Metabolic control of TH17 and induced Treg cell balance by an epigenetic mechanism. Nature (2017) 548:228-33. doi: 10.1038/nature23475

90. Johnson MO, Wolf MM, Madden MZ, Andrejeva G, Sugiura A, Contreras DC, et al. Distinct regulation of Th17 and Th1 cell differentiation by glutaminase-dependent metabolism. Cell (2018) 175(7):1780-95. doi: 10.1016/j.cell.2018.10.001

91. Kier P, Penner E, Bakos S, Kalhs P, Lechner K, Volc-Platzer B, et al. Autoantibodies in chronic GVHD: high prevalence of antinucleolar antibodies. Bone Marrow Transplant (1990) 6(2):93-6.

92. Patriarca F, Skert C, Sperotto A, Zaja F, Falleti E, Mestroni R, et al. The development of autoantibodies after allogeneic stem cell transplantation is related with chronic graft-vs-host disease and immune recovery. Exp Hematol (2006) 34(3):389-96. doi: 10.1016/j.exphem.2005.12.011

93. Svegliati S, Olivieri A, Campelli N, Luchetti M, Poloni A, Trappolini S, et al. Stimulatory autoantibodies to PDGF receptor in patients with extensive chronic graft-versus-host disease. Blood (2007) 110(1):237-41. doi: 10.1182/ blood-2007-01-071043

94. Nakasone H, Tian L, Sahaf B, Kawase T, Schoenrock K, Perloff S, et al. Allogeneic HY antibodies detected 3 months after female-to-male HCT predict chronic GVHD and nonrelapse mortality in humans. Blood (2015) 125(20):3193-201. doi: 10.1182/blood-2014-11-613323

95. Sarantopoulos S, Ritz J. Aberrant B-cell homeostasis in chronic GVHD. Blood. (2015) 125(11):1703-7. doi: 10.1182/blood-2014-12-567834 
96. De Masson A, Bouaziz JD, Le Buanec H, Robin M, O'Meara A, Parquet N, et al. CD24(hi)CD27+ and plasmablast-like regulatory B cells in human chronic graft-versus-host disease. Blood (2015) 125(11):1830-9. doi: 10.1182/blood-2014-09-599159

97. Solomon SR, Sizemore CA, Ridgeway M, Zhang X, Smith J, Brown S, et al. Corticosteroid-free primary treatment of chronic extensive graft-versus-host disease incorporating rituximab. Biol Blood Marrow Transplant (2015) 21 (9):1576-82. doi: 10.1016/j.bbmt.2015.04.023

98. Malard F, Labopin M, Yakoub-Agha I, Chantepie S, Guillaume T, Blaise D, et al. Rituximab-based first-line treatment of cGVHD after allogeneic SCT: results of a phase 2 study. Blood (2017) 130(20):2186-95. doi: 10.1182/ blood-2017-05-786137

99. Kim SJ, Lee JW, Jung CW, Min CK, Cho B, Shin HJ, et al. Weekly rituximab followed by monthly rituximab treatment for steroid-refractory chronic graft-versus-host disease: results from a prospective, multicenter, phase II study. Haematologica (2010) 95(11):1935-42. doi: 10.3324/ haematol.2010.026104

100. Seidel MG. Autoimmune and other cytopenias in primary immunodeficiencies: pathomechanisms, novel differential diagnoses, and treatment. Blood (2014) 124(15):2337-44. doi: 10.1182/blood-2014-06583260

101. Buxbaum NP, Pavletic SZ. Autoimmunity following allogeneic hematopoietic stem cell transplantation. Front Immunol (2020) 11:2017. doi: 10.3389/fimmu.2020.02017

102. Rawlings DJ, Metzler G, Wray-Dutra M, Jackson SW. Altered B cell signalling in autoimmunity. Nat Rev Immunol (2017) 17(7):421-36. doi: 10.1038/nri.2017.24

103. Kuraoka M, Snowden PB, Nojima T, Verkoczy L, Haynes BF, Kitamura D, et al. BCR and endosomal TLR signals synergize to increase AID expression and establish central B cell tolerance. Cell Rep (2017) 18(7):1627-35. doi: 10.1016/j.celrep.2017.01.050

104. Isnardi I, Ng YS, Srdanovic I, Motaghedi R, Rudchenko S, von Bernuth H, et al. IRAK-4 and MyD88-dependent pathways are essential for the removal of developing autoreactive B cells in humans. Immunity (2008) 29(5):746-57. doi: 10.1016/j.immuni.2008.09.015

105. Becker-Herman S, Meyer-Bahlburg A, Schwartz MA, Jackson SW, Hudkins $\mathrm{KL}$, Liu C, et al. WASp-deficient B cells play a critical, cell-intrinsic role in triggering autoimmunity. J Exp Med (2011) 208(10):2033-42. doi: 10.1084/ jem. 20110200

106. Kolhatkar NS, Brahmandam A, Thouvenel CD, Becker-Herman S, Jacobs HM, Schwartz MA, et al. Altered BCR and TLR signals promote enhanced positive selection of autoreactive transitional B cells in Wiskott-Aldrich syndrome. J Exp Med (2015) 212(10):1663-77. doi: 10.1084/jem.20150585

107. Smulski CR, Eibel H. BAFF and BAFF-receptor in B cell selection and survival. Front Immunol (2018) 9:2285. doi: 10.3389/fimmu.2018.02285

108. Warnatz K, Salzer U, Rizzi M, Fischer B, Gutenberger S, Böhm J, et al. B-cell activating factor receptor deficiency is associated with an adult-onset antibody deficiency syndrome in humans. Proc Natl Acad Sci U.S.A. (2009) 106(33):13945-50. doi: 10.1073/pnas.0903543106

109. Schweighoffer E, Vanes L, Nys J, Cantrell D, McCleary S, Smithers N, et al. The BAFF receptor transduces survival signals by co-opting the $\mathrm{B}$ cell receptor signaling pathway. Immunity (2013) 38(3):475-88. doi: 10.1016/ j.immuni.2012.11.015

110. Groom JR, Fletcher CA, Walters SN, Grey ST, Watt SV, Sweet MJ, et al. BAFF and MyD88 signals promote a lupuslike disease independent of T cells. J Exp Med (2007) 204(8):1959-71. doi: 10.1084/jem.20062567

111. Suthers AM, Sarantopoulos S. TLR7/TLR9- and B cell receptor-signaling crosstalk: promotion of potentially dangerous B cells. Front Immunol (2017) 8:775. doi: $10.3389 /$ fimmu.2017.00775

112. Thien M, Phan TG, Gardam S, Amesbury M, Basten A, Mackay F, et al. Excess BAFF rescues self-reactive $B$ cells from peripheral deletion and allows them to enter forbidden follicular and marginal zone niches. Immunity (2004) 20(6):785-98. doi: 10.1016/j.immuni.2004.05.010

113. Lesley R, Xu Y, Kalled SL, Hess DM, Schwab SR, Shu HB, et al. Reduced competitiveness of autoantigen-engaged $\mathrm{B}$ cells due to increased dependence on BAFF. Immunity (2004) 20(4):441-53. doi: 10.1016/S1074-7613(04) 00079-2
114. Avery DT, Kalled SL, Ellyard JI, Ambrose C, Bixler SA, Thien M, et al. BAFF selectively enhances the survival of plasmablasts generated from human memory B cells. J Clin Invest (2003) 112(2):286-97. doi: 10.1172/JCI18025

115. Rozmus J, Kariminia A, Abdossamadi S, Storer BE, Martin PJ, Lee SJ, et al. Comprehensive B cell phenotyping profile for chronic graft-versus-host disease diagnosis. Biol Blood Marrow Transplant (2019) 25(3):451-8. doi: 10.1016/j.bbmt.2018.11.007

116. Sarantopoulos S, Stevenson KE, Kim HT, Bhuiya NS, Cutler CS, Soiffer RJ, et al. High levels of B-cell activating factor in patients with active chronic graft-versus-host disease. Clin Cancer Res (2007) 13(20):6107-14. doi: 10.1158/1078-0432.CCR-07-1290

117. Flynn R, Allen JL, Luznik L, MacDonald KP, Paz K, Alexander KA, et al. Targeting Syk-activated B cells in murine and human chronic graft-versushost disease. Blood (2015) 125(26):4085-94. doi: 10.1182/blood-2014-08595470

118. Allen JL, Tata PV, Fore MS, Wooten J, Rudra S, Deal AM, et al. Increased BCR responsiveness in B cells from patients with chronic GVHD. Blood (2014) 123(13):2108-15. doi: 10.1182/blood-2013-10-533562

119. Lau A, Avery DT, Jackson K, Lenthall H, Volpi S, Brigden H, et al. Activated PI3K $\delta$ breaches multiple B cell tolerance checkpoints and causes autoantibody production. J Exp Med (2020) 217(2):e20191336. doi: 10.1084/jem.20191336

120. Xing H, Du X, Weng J, Lu Z. Phosphoinositide-3-kinase plays a vital role in graft-versus-host disease after allogeneic hematopoietic stem cells transplantation. Blood (2008) 112(11):4363. doi: 10.1182/blood.V112.11. 4363.4363

121. Paz K, Flynn R, Du J, Tannheimer S, Johnson AJ, Dong S, et al. Targeting PI3K $\delta$ function for amelioration of murine chronic graft-versus-host disease. Am J Transplant (2019) 19(6):1820-30. doi: 10.1111/ajt.15305

122. Ng YS, Wardemann H, Chelnis J, Cunningham-Rundles C, Meffre E, et al. Bruton's tyrosine kinase is essential for human B cell tolerance. J Exp Med (2004) 200(7):927-34. doi: 10.1084/jem.20040920

123. Vitale C, Ahn IE, Sivina M, Ferrajoli A, Wierda WG, Estrov Z, et al. Autoimmune cytopenias in patients with chronic lymphocytic leukemia treated with ibrutinib. Haematologica (2016) 101(6):e254-8. doi: 10.3324/ haematol.2015.138289

124. Vitale C, Montalbano MC, Salvetti C, Boccellato E, Griggio V, Boccadoro M, et al. Autoimmune complications in chronic lymphocytic leukemia in the era of targeted drugs. Cancers (Basel) (2020) 12(2):282. doi: 10.3390/ cancers 12020282

125. Jaglowski SM, Blazar BR. How ibrutinib, a B-cell malignancy drug, became an FDA-approved second-line therapy for steroid-resistant chronic GVHD. Blood Adv (2018) 2(15):2012-9. doi: 10.1182/bloodadvances.2018013060

126. Miklos D, Cutler CS, Arora M, Waller EK, Jagasia M, Pusic I, et al. Ibrutinib for chronic graft-versus-host disease after failure of prior therapy. Blood (2017) 130(21):2243-50. doi: 10.1182/blood-2017-07-793786

127. Quek LS, Bolen J, Watson SP. A role for bruton's tyrosine kinase (Btk) in platelet activation by collagen. Curr Biol (1998) 8(20):1137-40. doi: 10.1016/ S0960-9822(98)70471-3

128. Levade M, David E, Garcia C, Laurent PA, Cadot S, Michallet AS, et al. Ibrutinib treatment affects collagen and von Willebrand factor-dependent platelet functions. Blood (2014) 124(26):3991-5. doi: 10.1182/blood-201406-583294

129. Shatzel JJ, Olson SR, Tao DL, McCarty OJT, Danilov AV, DeLoughery TG, et al. Ibrutinib-associated bleeding; pathogenesis, management, and risk reduction strategies. J Thromb Haemost (2017) 15(5):835-47. doi: 10.1111/ jth.13651

130. Long M, Beckwith K, Do P, Mundy BL, Gordon A, Lehman AM, et al. Ibrutinib treatment improves $\mathrm{T}$ cell number and function in CLL patients. J Clin Invest (2017) 127(8):3052-64. doi: 10.1172/JCI89756

131. Zerr P, Palumbo-Zerr K, Distler A, Tomcik M, Vollath S, Munoz LE, et al. Inhibition of hedgehog signaling for the treatment of murine sclerodermatous chronic graft-versus-host disease. Blood (2012) 120 (14):2909-17. doi: 10.1182/blood-2012-01-403428

132. Olivieri A, Locatelli F, Zecca M, Sanna A, Cimminiello M, Raimondi R, et al. Imatinib for refractory chronic graft-versus-host disease with fibrotic features. Blood (2009) 114(3):709-18. doi: 10.1182/blood-2009-02-204156 
133. Baird K, Comis LE, Joe GO, Steinberg SM, Hakim FT, Rose JJ, et al. Imatinib mesylate for the treatment of steroid-refractory sclerotic-type cutaneous chronic graft-versus-host disease. Biol Blood Marrow Transplant (2015) 21 (6):1083-90. doi: 10.1016/j.bbmt.2015.03.006

134. DeFilipp Z, Nazarian RM, El-Jawahri A, Li S, Brown J, Del Rio C, et al. Phase 1 study of the Hedgehog pathway inhibitor sonidegib for steroid-refractory chronic graft-versus-host disease. Blood Adv (2017) 1(22):1919-22. doi: 10.1182/bloodadvances.2017011239

135. Bader-Meunier B, Bonafe L, Fraitag S, Breton S, Bodemer C, Baujat G, et al. Mutation in MMP2 gene may result in scleroderma-like skin thickening. Ann Rheum Dis (2016) 75(1):e1. doi: 10.1136/annrheumdis2015-208182

136. Kitko CL, Saliba R, Choi SW, Reddy P, Goldstein SC, Magenau J, et al. Biomarkers of extracellular matrix remodelling in chronic GvHD. Biol Blood Marrow Transplant (2013) 19(2):S332. doi: 10.1016/j.bbmt.2012.11.504

137. Wu CS, Yu CL, Wu CS, Lan CCE, Yu HS, et al. Narrow-band ultraviolet-B stimulates proliferation and migration of cultured melanocytes. Exp Dermatol (2004) 13(12):755-63. doi: 10.1111/j.0906-6705.2004.00221.x

138. Sorenson E, McAndrew R, Patel V, Logan AC, Koo J, Levin E, et al. Narrowband UV-B phototherapy for steroid-refractory sclerotic chronic cutaneous graft-vs-host disease. JAMA Dermatol (2015) 151(6):635-7. doi: 10.1001/jamadermatol.2015.0175

139. Loeys BL, Gerber EE, Reigert-Johnson D, Iqbal S, Whiteman P, McConnell V, et al. Mutations in fibrillin-1 cause congenital scleroderma: stiff skin syndrome. Sci Transl Med (2010) 2(23):23ra20. doi: 10.1126/scitranslmed. 3000488
140. Gerber EE, Gallo EM, Fontana SC, Davis EC, Wigley FM, Huso DL, et al. Integrin-modulating therapy prevents fibrosis and autoimmunity in mouse models of scleroderma. Nature. (2013) 503(7474):126-30. doi: 10.1038/ nature 12614

141. Kekre N, Kim HT, Ho VT, Koreth J, Armand P, et al. Phase II trial of natalizumab (Tysabri ${ }^{\circledR}$ ) with corticosteroids as initial treatment of gastrointestinal acute graft versus host disease. Biol Blood Marrow Transplant (2018) 24(3):S81. doi: 10.1016/j.bbmt.2017.12.649

142. Chen YB, Shah NN, Renteria AS, Cutler C, Jansson J, Akbari M, et al. Vedolizumab for prevention of graft-versus-host disease after allogeneic hematopoietic stem cell transplantation. Blood Adv (2019) 3(23):4136-46. doi: 10.1182/bloodadvances.2019000893

Conflict of Interest: The author declares that the research was conducted in the absence of any commercial or financial relationships that could be construed as a potential conflict of interest.

The reviewer DW declared a past co-authorship with the author JR to the handling editor.

Copyright (C) 2021 Rozmus. This is an open-access article distributed under the terms of the Creative Commons Attribution License (CC BY). The use, distribution or reproduction in other forums is permitted, provided the original author(s) and the copyright owner(s) are credited and that the original publication in this journal is cited, in accordance with accepted academic practice. No use, distribution or reproduction is permitted which does not comply with these terms. 